\title{
Understanding of Marriage Law Attitude For Delivery of Early Age Marriage in Indonesian Adolescence
}

\author{
Agoes Dariyo ${ }^{1}$, Mia Hadiati ${ }^{2}$, R. Rahaditya ${ }^{3}$, \\ \{agoesd@fpsi.untar.ac.id ${ }^{1}$, miahadiati@fh.untar.ac.id ${ }^{2}$, rahaditya@mku.untar.ac.id ${ }^{3}$ \} \\ ${ }^{1}$ Faculty of Psychology Universitas Tarumanagara Jakarta, Indonesia, \\ ${ }^{2,3}$ Faculty of Law Universitas Tarumanagara Jakarta, Indonesia,
}

\begin{abstract}
This research is a quantitative empirical study that examines the understanding of marital law (Law No. 1 of 1974) which forms emotional maturity, so that someone makes a decision to delay early marriage. Data collection using questionnaires is an understanding of marital law, emotional maturity and delaying early marriage. The number of subjects involved in this study were 62 people, 18-22 years old adolescents. Analysis techniques using a correlation test and it was found that there was a significant relationship between the understanding of marital law and the delay of early marriage $(r$ $=.310, \mathrm{p}=.001, \mathrm{p}<.01)$, there was a significant relationship between understanding legal marriage with emotional maturity $(\mathrm{r}=.224, \mathrm{p}=.031, \mathrm{p}<.05)$, and there was a significant relationship between emotional maturity and delay in early marriage $(\mathrm{r}=.280$, $\mathrm{p}=.002, \mathrm{p}<.01)$. Next, it will be explained in detail in this article.
\end{abstract}

Keywords: understanding attitude of law number 1 of 1974, emotional maturity, delivery of early age marriage, adolescence.

\section{Introduction}

Child marriage performed by some children in Palembang (South Sumatra), Banjarmasin (South Kalimantan), Mamju (West Sulawesi) and Makassar (South Sulawesi) has become widely reported by print and electronic media (Detiknews.com, 2019; Kompas .com, 2019). The child's marriage event invites views that are pro and contra. The pro's view states that marriage is the right of every person to marry and continue a legitimate offspring (Article $28 \mathrm{~b}$ of the 1945 Constitution). Early marriage is an effort to prevent siri marriage (underhand marriage) (Helnawaty, 2005). Marriage is an effort to carry out religious faith and keiklasan, so that everyone has the right to carry out the marriage (Santoso, 2016). According to Zubaidah (2019) that with the approach of Islamic law. Early marriage is considered an effort to overcome and prevent adultery among teenagers in Indonesia. Early marriage can be done by teenagers who have received approval from both parents.

The contradictory view states that child marriage will lead to divorce (Priohutomo, 2018; Zubaidah, 2019), because the two married couples are not physiologically and psychologically mature (Papalia \& Martorell, 20XX), so that they are unable to control emotions if they face various problems in his life. The Minister of Religion of the Republic of Indonesia, Lukman Hakim Saifuddin, said that divorce rates in Indonesia are high (Kumparan News, 2018). Data for 2016 for example, divorce rates reached $19.9 \%$ of 1.8 million events. While for 2017 data, the figure reached $18.8 \%$ of the 1.9 million divorce events (News Era, 2018). The Central 
Statistics Agency (2018) mentions an increase in divorce rates by $2.3 \%$ in Indonesia, namely in 2015 (353 843 cases), 2016 (365 654 cases) and in 2017 (374 516 cases). Every day the office of religious belief determines divorce among couples who apply for divorce.

Divorce can occur between married couples because both are unable to manage their emotions when they face various pressures of life in the household (Wang \& Amato, 2000; Heaton, Cammack \& Young, 2001). Those who do not have emotional maturity prefer to divorce rather than trying to maintain the integrity of their family. Meanwhile, the result of divorce from a married couple will have a negative impact on the psychological conditions felt by children (Booth \& Amato, 2001; Furstenberg \& Kuernan, 2001). They feel shocked, traumatized, insecure, scared, anxious or worried about their lives. Children's lives become erratic, neglected and tend to be ignored by both parents (Jenkin, 2000). Thus, they feel pessimistic about the future of their lives (Fuerstenberg \& Kuernan, 2001; Jacquet \& Surra, 2001; Lin, Schaeffer \& Selitzer, 2004). So emotional maturity is an important foundation for everyone who wants to get married and shape household life (Aminulah, 2017). .

Emotional maturity as a condition experienced by an individual to be able to understand the dynamics of his emotions so that he is able to manage his emotional state to adjust to the social environment (Walgito, 2007; Dariyo \& Tumanggor, 2016). Because each individual is required to be able to adapt to the social environment of a society that is full of diversity in religion, culture or customs (Kalmijn, De Graaf \& Poortman, 2004). Therefore, a person's ability to understand the emotional state of himself and others plays an important role in adjusting to society. Thus, an emotionally mature person will benefit himself, because he will be able to make a good decision (Puspasari, 2016) so that he can behave, act and behave in accordance with the demands of the values, norms and social rules of society (Walgito, 2007).

Emotional maturity of growth in a person through understanding the number 1 of 1974 concerning marriage. Article 1 of Law No. 1 of 1974 states that marriage is an inner and outer bond between a man and a woman as husband and wife with the aim of forming a happy and eternal family based on the One Godhead. Understanding, living and practicing the 1974 Law on marriage is an obligation for every Indonesian citizen. Every citizen must be responsible for his personal life in order to realize happiness and prosperity of his life (Fowers \& Olson, 1993).

In the research problem formulation is presented, namely (a) whether the understanding of law number 1 concerning marriage plays a role in delaying early marriage in adolescents (b) whether the understanding of law number 1 about marriage has a role in forming emotional maturity, so that adolescents do postponing early marriage. In addition, in this study hypotheses are proposed, namely (a) there is a relationship between marital law understanding with early adolescence delay adolescence, (b) there is a significant relationship of understanding number 1 concerning marriage plays a role to shape emotional maturity, so that adolescents do postponing early marriage.

\section{Method}

The subjects involved in this study were adolescents in the age range of 18-22 years. Men $(15 / 14,2 \%)$ and women $(47 / 75.8 \%)$. The majority of the subjects came from the Chinese (44 people / 66.1\%) and the rest came from Javanese, Batak, Sundanese and so on (18 people / 33.9\%). Retrieval of data using questionnaires, namely an understanding of marital law, emotional maturity and postponement of early marriage. The three measuring instruments 
have met the validity and reliability test requirements (see table). The data analysis technique with correlation test and the results can be seen in table 1 below.

Table 1. Validity and reliability of Instrument

\begin{tabular}{lllcc}
\hline No & \multicolumn{1}{c}{ Variabel } & Item & $\begin{array}{c}\text { Validity } \\
\text { Corrected Item-Total Correlation }\end{array}$ & $\begin{array}{c}\text { Reliability } \\
\text { Alpha chronbach }\end{array}$ \\
\hline 1 & Law of Marriage of 1974 & 7 & $.277-.490$ & .646 \\
2 & Delivery of Marriage & 11 & $.210-.709$ & .873 \\
3 & Emotion maturity & 12 & $.313-.628$ & .818 \\
\hline
\end{tabular}

Test assumptions

Through testing the assumption that the variables of marriage law and postponement of marriage are classified as normal distributions, while emotional maturity variables are classified as abnormal distribution (table 2).

Tabel 2. Normality Test

\begin{tabular}{llllll}
\hline No & \multicolumn{1}{c}{ Variabel } & Komolgorof- smirnov test & $\mathbf{p}$ & Significancy & \multicolumn{1}{c}{ Note } \\
\hline 1 & Law of Marriage of 1974 & .200 & .05 & $\mathrm{P}>.05$ & Normal \\
2 & Delivery of Marriage & .200 & .05 & $\mathrm{P}>.05$ & Normal \\
3 & Emotion maturity & .037 & .05 & $\mathrm{P}<.05$ & Non normal \\
\hline
\end{tabular}

\section{Result and Discussion}

According to Nisfiannor (2013) if the assumption test is not fulfilled properly in a correlation test, then the data must be tested with a non-parametric test approach. In testing the assumption that all variables do not meet the normality and linearity test. Therefore, in this study the data were tested with a non-parametric approach, namely the correlation test of Kendal Tau . Furthermore, it is known that there is a significant relationship between the understanding of marital law and the delay in early marriage $(r=.310, p=.010, p<.01)$, there is a significant relationship between understanding legal marriage with emotional maturity $(\mathrm{r}=$ $.224, \mathrm{p}=.031, \mathrm{p}<.05)$, and there is a significant relationship between emotional maturity and delay in early marriage $(\mathrm{r}=.280, \mathrm{p}=.001, \mathrm{p}<.01)($ table 3$)$.

Table 3. Corelation test of kendal tau

\begin{tabular}{llcc}
\hline No & Variables & 1 & 2 \\
\hline 1 & Law of Marriage of 1974 & - & - \\
2 & Delivery of Marriage & $.310^{* *}$ & - \\
3 & Emotion maturity & $.224^{*}$ & $.280^{* *}$ \\
\hline
\end{tabular}

$* * \mathrm{p}<.001$

$* \mathrm{p}<.005$

The results showed that there was a significant relationship of understanding the number 1 of 1974 law on marriage with the delay of early marriage in adolescents. Article 1 of Law Number 1 of 1974 concerning marriage states that the marriage is an inner bond between a man and a woman as husband and wife who aims to form a happy and eternal family based on 
the One Godhead. The birth bond means that a marriage is a bond of physiological, psychological and spiritual aspects. A person carrying out a marriage is not only a biological element, in which a person merely distributes sexual libido needs, but there are still psychological and spiritual elements that must be considered with the best (Nasution, 2005; Ashsubli, 2015). When someone has made the decision to marry and form a family, he must be brave enough to be responsible for maintaining the integrity of his family. Someone is required to have a commitment in an effort to maintain the integrity of the family (Scorpio, 2011). A man must be able to meet the economic needs of his family (Rogers, 1999; Zhang, 2004). A woman must be able to raise children born into her family. Therefore, if someone is not ready mentally, then he should delay getting married at an early age (Priohutomo, 2018).

The results also showed that there was a significant relationship between the understanding of law number 1 of 1974 concerning marriage and emotional maturity, so that a teenager postponed early marriage. Marriage is based on the supreme divinity, meaning that a marriage must be based on elements of faith or similarity in religion / belief. If someone chooses a prospective wife or prospective husband, then he must pay attention to the background of religion, faith or belief in the candidate for his life partner. In this case, this law would like to emphasize how important it is to marry a prospective partner whose religion is the same. Indonesia is indeed a plural country that recognizes 6 religions (Islam, Christianity, Catholicism, Hinduism, Buddhism, Kong Hucu). According to Ashsubli (2015) that interfaith marriage is not strictly prohibited in the marriage law. However, it would be nice for someone to marry a partner whose religion is the same. This is to avoid unwanted problems in the future, such as divorce between husband and wife who are motivated by religious differences.

By understanding the principle of marriage as an inner and outer bond based on the Almighty Godhead (Hooper, 2001), one always considers everything before making a decision to do a marriage. A person must be able to prepare himself mentally (mental readiness). Mental terms include cognitive, affective and conative elements. But in a narrow sense, mental readiness is more interpreted as emotional maturity (Walgito, 2007). Emotional maturity as an expression of understanding of the conditions of emotional dynamics that occur in one's life. Emotional maturity is characterized by the ability to manage the condition of his emotions so that they can be controlled in such a way that a person is able to adjust to the social environment of society (Alexander, 1948). Every emotional turmoil that arises from within, a person is always able to understand and manage it to realize behaviors, attitudes, actions and actions that can benefit themselves and others around them.

Emotionally mature people are characterized by the ability to accept themselves and others (self-acceptance), self-confidence, responsibility, and management of emotions. He is able to accept himself both the advantages and weaknesses of himself. Only, he is also able to accept other people as they are. An emotionally mature person, he feels confident about his speech, actions and actions in the social environment (Walgito, 2007). For people who are mature emotions, then he will be responsible for anything that is said, done or done in the context of the social environment. Therefore, people who are emotionally mature, always behave wisely. He is able to understand his emotional dynamics and manage emotions so that they can be expressed through the attitudes, attitudes, actions and actions that can be ethically accountable that apply in the social environment of the community.

Therefore, emotionally mature people always think carefully before doing something that has a long-term impact on life. He will think of the positive-negative effects of each decision he will make. Emotional maturity has an important role to play in one's ability to make good decisions (Puspasari, 2016). Decision making must be based on mastering important information related to information relating to marital problems, especially marriage law. By 
understanding the legal basis that marriage is an inner bond between a man and a woman who will form a family, then one must be able to prepare well. Not immediately, someone immediately takes the decision to get married, but he must prepare himself physically and mentally, meaning he must have physiological and psychological readiness. In the study of developmental psychology (development psychology) that a person is considered to have physiological readiness to undergo a marriage period, namely those who already have reproductive maturity. They have primary sexual maturity (primary sexual) and secondary sexual maturity (secondary sexual) (Papalia \& Martorell, 20XX). Thus, someone is ready to carry out the reproductive function, where a person is able to carry out his duties as a husband and wife. They are ready to form a family and have a family. A woman is ready to get pregnant, give birth to a baby and take care and care for her to adulthood. Likewise, a man is responsible for being a father to head his household.

\section{Conclusion}

The attitude of understanding law number 1 of 1974 concerning marriage will shape the emotional maturity in Indonesian adolescents, so that he will be able to make the right decisions, namely delaying early marriage. Understanding the law number 1 of 1974 concerning marriage as an important foundation for considering every decision that is closely related to marital life. They prefer to delay early marriage, so that they prepare themselves to achieve their ideals by taking the highest education, after which they shape the marriage life based on attitudes, actions and actions that are in accordance with legal norms in Indonesia.

\section{Aknowledge}

The researchers would like to thank the Republic of Indonesia Ministry of Research and Higher Education and the Directorate of Research and Community Service of Universitas Tarumanagara (DPPM Untar) who funded this research activity.

\section{References}

[1] Ashsubli, M (2015). Undang-undang perkawinan dalam pluralitas hukum agama. Jurnal Cita Hukum, II (2), 289-301.

[2] Alexander, F (1948). Emotional maturity. Illinois Society for Mental Hiegiene, Mental Health Buletin, 1-8.

[3] Aminulah, (2017). Upaya Pendewasaan Usia Perkawinan. Tesis. Yogyakarta: Universitas Islam Negeri Sunan Kalijaga

[4] Badan Pusat Statistik (2018). Data statistik di Indonesia. Jakarta: BPS RI.

[5] Booth, A \& Amato, P. R. (2001). Parental predivorce relations and offspring postdivorce wellbeing. Journal of Marriage and the Family, 63, 197-212.

[6] Dariyo, A \& Tumanggor, R.O. (2016). Upaya mencegah perceraian: Peran Kematangan emosi dan resiliensi terhadap kepuasan perkawinan. Laporan penelitian. Jakarta: DPPM Untar.

[7] Dutta,J \& Rajkowar, N. (2015). Study on emotion maturity and Inteligence on Secondary School Student of Azam. International Journal of Science and Researh, 78-96. 
[8] Fosco, G. M \& Grych, J. H. (2007). Emotional expression in the family as a context for children's appraisal of interparental conflict. Journal of Family Psychology, 21 (2), 248-258.

[9] Fowers, B. J \& Olson, D. H. (1993). ENRICH marital satisfaction: A brief research and tool clinical. Journal of Family Psychology, 7 (2), 176 - 185.

[10] Furstenberg, F. K \& Kuernan, K. (2001). Delayed parental divorce: How much do children benefit? Journal of Marriage and Family, 63, 446-457.

[11] Heaton, T. B., Cammack, M., \& Young, L. (2001). Why is the divorce declining in Indonesia?. Journal of Marriage and Family, 63, 480-490.

[12] Helnawaty (2005). Fenomena pernikahan bawah tangan (siri) di kalangan mahasiswa perempuan. Depok: Universitas Gunadarma,

[13] Hooper, J. (2001). The symbolic origins of conflict in divorce. Journal of Marriage and Family, 63, 430-445.

[14] Jacquet, S. E \& Surra, C. A. (2001). Parental divorce and premarital couple: Commitment and other relationship characteristics. Journal of Marriage and Family, 63 (3), 627-638.

[15] Jenkin, J. M (2000). Marital conflict and children's emotion: The development of an anger organization. Journal of Marriage and Family, 62 (2), 723-736.

[16] Kalmijn, M., De Graaf, P. M \& Poortman, A.R. (2004). Interaction between cultural and economic determination of divorce in the Netherland. Journal of Marriage anf Family, 66 (1), 75-89.

[17] Kapri, U. C \& Rani, N. (2014). Emotion maturity: Characteristics and levels. International Journal of Technology and Learning, 3 (1), 359-361.

[18] Lin, I., Schaeffer, N. C., Seltzer, J. A., \& Tuschen, K. L. (2004). Divorced parents' qualitative and quantitative of children living arrangements. Journal of Marriage and Family, 66 (2), 385397.

[19] Nasution, K. (2005). Pengaruh gerakan wanita terhadap wacana hukum Islam: Studi hukum perkawinan Indonesia. Al-Mawarid, XIV, 255- 264.

[20] Nisfianoor, M. (2013). SPSS untuk Ilmu Sosial. Jakarta: Trisakti Press.

[21] Papalia, D.E \& Martorell, G. (20XX). Experience human development. (13th edition). New York: McGraw-Hill Education.

[22] Priohutomo, S. (2018). Mencegah perkawinan dini melalui program KKBPK. Makalah seminar. Banjarmasin: Seminar Nasional Kependudukan.

[23] Puspasari, D (2016). Hubungan antara kematangan emosi dengan pengambilan keputusan pada remaja. Skripsi. Surakarta: Fakultas Psikologi Universitas Muhamadiyah Surakarta.

[24] Rogers, S. J. (1999). Wives' income and marital quality: Are there reciprocal effects ?. Journal of Married and Family, 61 (1), 123-132.

[25] Santoso (2016). Hakekat perkawinan menurut undang-undang perkawinan, hukum islam dan hukum adat. Yudisia, 7 (2), 412-434.

[26] Scorpio, A. (2011). Gambaran bentuk komitmen perkawinan dari seorang istri yang memiliki suami pecandu narkoba. Buletin Ilmiah Psikologi Metamorfosis, 5 (20), 43-53.

[27] Undang-undang Nomo1 Tahun 1974 tentang Perkawinan.

[28] Walgito, B. (2007). Konseling perkawinan. Yogyakarta: Andy.

[29] Wang, H \& Amato, P.R. (2000). Predictors of divorce adjustment: Stressors, resources and definitions. Journal of Marriage and Family, 62 (2), 655-668.

[30] Zhang, Q. F. (2004). Economic transition and new pattern of parent-adilth child coresidence in Urban China. Journal of Marriage and Family, 66 (5), 1231- 1245.

[31] Zubaidah, N (2019). Child marriage and zina in Indonesia. Jurnal hukum dan pembangunan UI, 49 (1), 210-231.

[32] Era Berita (2018). Fakta di Balik Tingginya Angka Perceraian di Indonesia. Download 7 Mei 2019

[33] KumparanNews (2018). Menteri Agama: Angka Perceraian di Indonesia Meningkat. Download 7 Mei 2019. 
